\title{
Impact of Indonesian Capital Market Development on Economic Growth Through Labor Absorption and Per Capita Income (Time Series Study 1990 - 2020)
}

\author{
Almira Rizqia ${ }^{1}$, Musa Hubeis ${ }^{2}$, Pudji Astuty ${ }^{3}$ \\ \{almira.rizqia@gmail.com¹, hubeis.musa@yahoo.com², Pudji_astuty@borobudur.ac.id ${ }^{3}$ \} \\ Universitas Borobudur, Jakarta, Indonesia ${ }^{1,2,3}$
}

\begin{abstract}
The motivation behind this review is to break down the advancement of the Indonesian capital market fair and square of work assimilation and per capita pay. In this review, auxiliary information and library research were utilized as a method in gathering information, utilizing semiannual information for the period 1990-2020. The examination was handled utilizing the EViews 11 program with numerous straight relapse technique. The aftereffects of the exploration show that the improvement of the Indonesian capital market emphatically affects Indonesia's monetary development through the factors of Indonesia's Labor Absorption Rate and Income per Capita during the period 1990 to 2020. The consequences of this review are relied upon to have the option to add to strategy holders in regards to the job of Capital Market Development, so that in the future more extensive comprehensiveness can be done in regards to the job of the Capital Market in the public arena, especially being able to reach up to the village level or in Village Owned Enterprises (BumDes). So that with increasing public participation in investing and seeking funding in the Capital Market, the Indonesian Capital Market can be even more advanced in the future which has implications for the creation of new jobs and an increase in per capita income.
\end{abstract}

Keywords: Stock Market Index; Per capita Income; Economic Growth 


\section{Introduction}

Financial development is characterized as the advancement of monetary movement which brings about expanded items delivered locally and individuals become more prosperous. The issue of monetary development can be viewed as a macroeconomic issue in the long haul [1]. From between periods the ability of a country to produce goods and services will increase. This is because the factors of production will always increase in terms of quality and quantity. Investment will increase the total capital goods. The technology used will continue to develop.

In addition, the workforce increases due to population growth, and work experience and education increase skills. The development of the ability to produce products due to the increase in factors of production is usually not necessarily accompanied by the addition of the same product. The increased potential in producing a product often exceeds the actual increase in production. So that economic development is slower than its potential. Financial development depicts monetary movement. The worth of financial development can be positive or negative. In the event that in a time of positive monetary development, it implies that financial movement in the period concerned is increasing. Meanwhile, if in an economic period the growth is negative, it means that economic activity in the period concerned decreases.

According to Bilal Kagi [2], labor growth in economic theory is the reason for economic development, namely during a period of stable economic growth it is hoped that there will be a decrease in unemployment and an increase in employment. The data in the table below is the labor force data in 2020 with education levels from high school to university.

Table 1. Labor Absorption in Indonesia in 2020

\begin{tabular}{lrrr}
\hline & \multicolumn{3}{c}{ Workforce } \\
\cline { 2 - 4 } & \multicolumn{1}{c}{ Work } & Unemployment & Workforce Total \\
\hline Senior High School SMU & $20,413,413$ & $1,950,626$ & $22,364,039$ \\
Senior High School SMK & $12,170,267$ & $1,520,549$ & $13,690,816$ \\
Diploma & $3,416,119$ & 219,736 & $3,635,855$ \\
University & $11,087,318$ & 567,235 & $11,654,553$ \\
\hline Total & $\mathbf{4 7 , 0 8 7 , 1 1 7}$ & $\mathbf{4 , 2 5 8 , 1 4 6}$ & $\mathbf{5 1 , 3 4 5 , 2 6 3}$ \\
\hline
\end{tabular}

Source: Central Bureau of Statistics, processed

Table 1 shows that if the workforce in 2020 is more employed, namely 47,087,117 people compared to unemployment, which is $4,258,146$, Indonesia can absorb workers. In a business unit, the purpose of the company to employ labor is to support the production of goods and services which are then sold to the public, the increase in the level of demand for labor depends on how much the increase in public demand for a product is produced. So it must be known the relationship and the inequality between the terms of demand and the quantity of goods demanded in order to understand how much demand for goods produced is needed by the community.

Of late, the improvement of the capital market in Indonesia has been so speedy, making capital market players mindful that this trade can give remarkable returns and contribute hugely to cash related advancement in Indonesia. The amount of associations that open up to the world also, register their pieces in the capital market is confirmation of this condition. This, either clearly or indirectly, can maintain the improvement of the public capital market industry to an elevating level. Considering Article No. UUPM. 8 of 1995, it is explained that the capital market is practices related to public commitments and insurances trading, public associations related to gave securities, similarly as establishments and reasons for living 
related to assurances and securities or securities, which consolidate commitment confirmations, business assurances. , stocks, bonds, verification of commitment, support units in total hypothesis contracts, destinies contracts on insurances, and each auxiliary of securities.

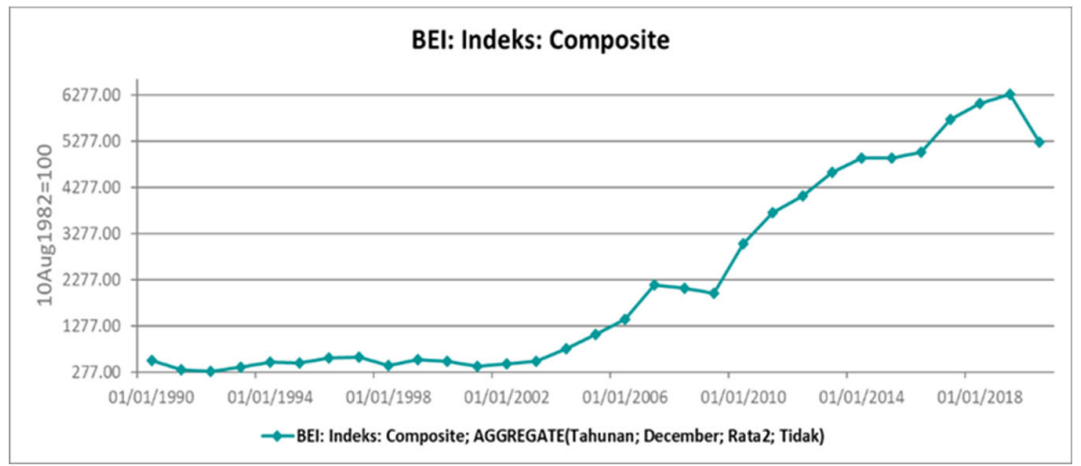

Fig. 1. Graph of Composite Stock Price Index (JCI) 1990-2018

Source: Indonesia Stock Exchange, processed

The Indonesian Composite Index layout starting with one year then onto the next shows an example of headway with the biggest number showing up at 6296 , this is verifiably consoling considering the way that it infers The Indonesian capital market is showing a positive development process. The capital market for organizations doesn't just offer advantages. The capital market is additionally a venture scene for financial backers, the individuals who have abundance assets, to have the option to contribute capital wanting to get a return. Financial backers can figure out which organization to put resources into to get ideal benefit. The advancement of the capital market as a speculation instrument establishment has monetary and monetary capacities that are progressively required by the local area as the favored medium and pledge drive. Financial backers who complete exchanges on the stock trade to choose in deciding a portfolio that can procure benefits, financial backers need data. Declaration of stock split or stock split is important for the data given. A Go Public organization that completes exercises fully intent on expanding the absolute exceptional offers is known as a stock split.

The expenditure policy of the Indonesian government stated in the APBD is something that has an influence on the level of employment. This policy is reflected in the total government expenditure used in the regional budget, government spending, investment which affects the absorption of labor [3] The existence of a APBD whose source is from central assistance and PAD is a manifestation of the accumulation of government capital used in spurring the economic growth of a region. The strategic role of government investment, the target of its use in funding development in the facilities and infrastructure sector, can encourage the smooth running of private businesses and the fulfillment of public services. However, if it is related to investment which is the key in creating jobs, it can be seen in the following graph: 


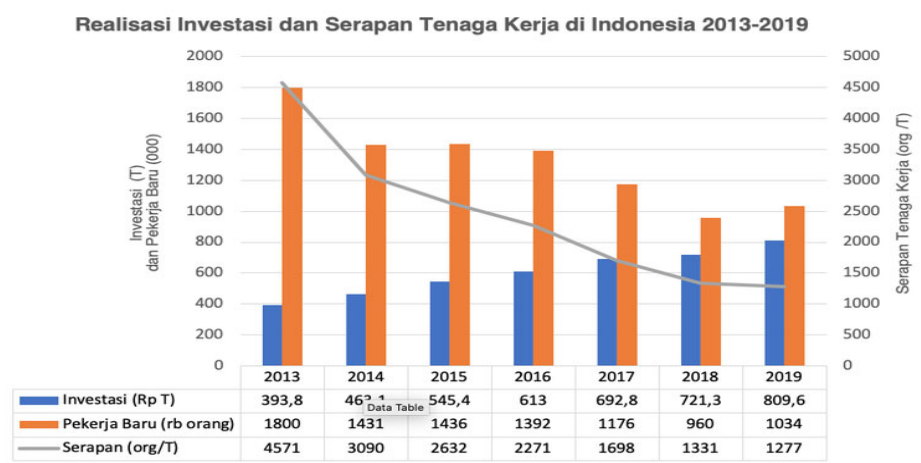

Fig. 2. Investment Realization and Labor Absorption in Indonesia 2013-2019

Source: BKPM, processed

From graph 2 above, it can be seen that the investment realization data is increasing but labor absorption actually decreases between years. This shows that the root cause of the unemployment problem in Indonesia is not caused by a lack of capital injection, even when investment performance in Indonesia is good, so this raises the question of why investment in Indonesia has less effect on job creation and improving the fate of its workers.

Gross Domestic Product (GDP) is an important factor in employment, because (GDP) is a measuring tool in knowing how a country's economic growth is. Traditionally, according to (Kuncoro, 2013), economic growth is shown in increasing sustainable gross domestic product. through (GDP) can be known how the economic growth of a country. Total production to GDP is the level of production of the total number of goods and services created from a sector of employment. Furthermore, another factor that has an influence on the occurrence of additional employment is investment.

According to previous research that examined the impact of capital market development on economic growth on employment, including [4] [5] and [6]. Research on the impact of capital market developments on economic growth on per capita income includes [7] [8] and [9].

The measure of the success of economic development can be seen from economic growth and thelower income gap between communities, between regions and fields [10]. Economic growth is usually measured using GDP, but this indicator is not necessarily accurate because it does not reflect actual growth. Another indicator is GDP Per capita which is a comprehensive indicator in knowing economic growth because it focuses more on the country's ability to increase GDP more than the level of population growth [11]. High economic growth can reflect an increase in people's welfare from an increase in production which results in people's consumption will increase which shows an increase in public opinion. However, this increase in production can only be felt by a number of minority groups, resulting in inequality. From the important foundation, the detailing of this exploration is:

1. Is there any influence on the Development of Indonesia's capital market at the level of labor absorption

2. Is there any influence of Indonesia's Capital Market Development on Per Capita Income

\section{Literature Review}

\subsection{Economic Theory}


The term "economy" comes from the Greek words (oikos) which means family, and nomos which means regulations, rules and laws. In general, the word economics is interpreted as regulation and management of households and the state. The word economics was first popularized by Xenophone ( $427 \mathrm{BC}$ ), which the term was later described in his work entitled Oikonomikus [12]

PA Samuelson's opinion [13], financial aspects is an investigation of how individuals and society settle on their decisions, with or without utilizing cash, using restricted assets yet can be utilized in different ways to make different kinds of labor and products and disperse them for utilization needs, presently and later on, for different individuals and gatherings of individuals.

Economics is a field of study that has long developed into a field of science, its development grew from 1776, namely after Adam Smith as a British thinker and market analyst distributed a book named "an investigation into the nature and reason for the abundance of countries." A number of points of view in his book still receive attention in the thinking of economists today. Adam Smith can be considered the "father of economics". the type of economic activity of the country as a whole is certainly not the same. [1]

\subsection{Indonesian Capital Market Development}

The cash related market for executing long assets resembles a liberal market, a comprehension of the capital market. Spots utilized for the advancement of stocks and security, whose business continues can be utilized as extra assets or backing the capital of the association [14] Not in the law. Decree No. 8 of 1995 also has a similar interpretation of the capital market, which was exposed as activities related to public undertakings and securities transactions, associations related to guarantee issuance, and offices and telephones identified with gave protections, and offices and callings identified with protections. The capital market is an important component as well as a benchmark for the progress of a nation's economy. Every country must have a capital market except for countries that are lagging behind and need improvement in their government. [15].

\subsection{Labor Absorption Rate}

The problem that arises from the absorption of labor is the imbalance between supply and demand in a certain level of compensation. This general condition arises due to the excessive supply of labor in each sector. But on the other hand, the number of people looking for work and unemployed is increasing. This condition has consequences for the sustainability of the business of providing job opportunities for the new workforce [16].

The problem of absorption of labor is generally related to the growth and development that occurs in the area, due to the existence of development and growth. Based on its objectives, a region is expected to get prosperity. Through the fulfillment of all primary, secondary, and tertiary needs using sufficient income, when the community group has a job.Employment is a workforce that works inside and outside the employment relationship. All activities that use the main production equipment of a job. The main means of production is the production process of the workforce, which consists of either the physical or the mind (Law No. 13 of 2003 concerning Manpower).

\subsection{Income per capita}


The sum of all the money an individual earns in a given period of time is called income. Salaries, income from wealth such as rent, interest and securities as well as receipts or payments such as social benefits or unemployment assumptions are various components of income [17]

The opinion of [18] states that if a product or service that can be consumed within a certain period of time is the meaning of income. Then the average income of people in a country within a certain period of time which generally occurs during a year is called per capita income [1] says that the average income of the population of a country or region in a certain period is usually one year. The results of the division of regional income by the number of residents are used as the basis for calculating per capita income. In a country the measure of prosperity and level of development is often used as a measure of per capita income.

\subsection{Hypothesis}

Moving on from the background that has been described, the following hypotheses can be formulated:

1. Hypothesis 1: The development of the capital market has a significant and positive impact on the labor absorption rate

2. Hypothesis 2: Capital Market Developments have a significant and positive impact on Per Capita Income

\section{Methods}

The data used in this review is discretionary data where the arrangement uses time series data for quite a while, to be unequivocal from 1990-2020 with data confined per semester. The data gathered by the specialists came from various sources related to the assessment subject, unequivocally the Central Statistics Agency, Bank Indonesia, the World Bank and the Indonesia Stock Exchange.

Variable assessment method and judicious definition used is a causal relationship model between the free component and the dependent variable. A statement explaining the Agreement structure "When no under two examples of a given eccentricity share one and only one condition for all targets and reason then that condition may be considered to be the guard for the brand name" is the appraisal of John Stuart Mill in [19]The theorem of agreement in this study can be formulated by:

1. Labor Absorption Rate $=Z_{1}$, the function of the dependent variable and is an intermediate variable that is partially influenced by the independent factor $(Z)$, then the model format is as follows: $\mathrm{Z}_{1}=\mathrm{f}(\mathrm{Y})$

2. Income per Capita $=Z_{2}$, the function of the dependent variable and is an intermediate variable that is partially influenced by the independent factor $(Z)$, then the model format is as below: $\mathrm{Z}_{2}=\mathrm{f}(\mathrm{Y})$

3. The regression analysis technique in this study uses an approach with an equation model :

a. Model I

$$
Z=\beta_{0}+\beta_{1} Y+€ t
$$

b. Model II

$$
Z_{1}=\beta_{0}+\beta_{1} Z+€ t
$$

With :

$\beta_{0} \ldots . . \mathrm{n}=$ Constant Equation $1 \mathrm{~s} / \mathrm{d} \mathrm{n}$ 
$€_{1} \ldots . . \mathrm{n}=$ Standar Error of Equation $1 \mathrm{~s} / \mathrm{d} \mathrm{n}$

$\mathrm{Y}=$ Capital Market Development

$Z_{1}=$ Labor Absorption Rate

$\mathrm{Z}_{2}=$ Income per Capita

Multicollinearity test using matrix correlation test [20] Normality test using Jarques-Berra [20] Autocorrelation using Langrange Multiplier or Breusch Gordfrey test [20], detecting heteroscedasticity using White Heteroskedasticity Test [20]. To see if the time series information utilized is fixed or not, the fixed test (unit root test) is utilized. In research, essentially time series information frequently experience non-fixed at the series level. So it is important to do separation a few times to deliver fixed information. The unit root test was completed utilizing the Augmented Dicky Fuller (ADF) method.Partial theory test utilizing ttest with alpha 0.005 . The coefficient of assurance (R2) is utilized to gauge the model's capacity to clarify the free factors [20].

\section{Result and Discussion}

\subsection{Result}

\subsubsection{Unit Root Test and Classical Assumptions}

Testing the unit root pack at the primary differentiation level for all elements using the ADF (Augmented Dickey-Fuller) methodology conveys the ADF a motivating force for the capital market improvement variable of 8.224303 with Prob. the worth of $0.0000<=0.05$, the $\mathrm{ADF}$ an incentive for the work retention variable is 4.076822 with Prob. The worth of 0.0022 $<=0.05$, the ADF an incentive for the pay per capita factor is 7.326845 with Prob. The worth is $0.0000<=0.05$ at that level. As such, it is communicated that all proper elements at the resulting level and conditions are cointegrated, or don't convey spurios backslide for the three models. The eventual outcomes of the conventional notion test communicated that the three models had met the principles of commonness, multicollinearity, autocorrelation, and heteroscedasticity or were broadcasted to meet.

\subsubsection{Descriptive Analysis}

Based on data from the Indonesia Stock Exchange, the Composite Stock Price Index (JCI) during the 30 (thirty) research period 1990-2020 with semester data contained 62 (sixty-two) research samples. 


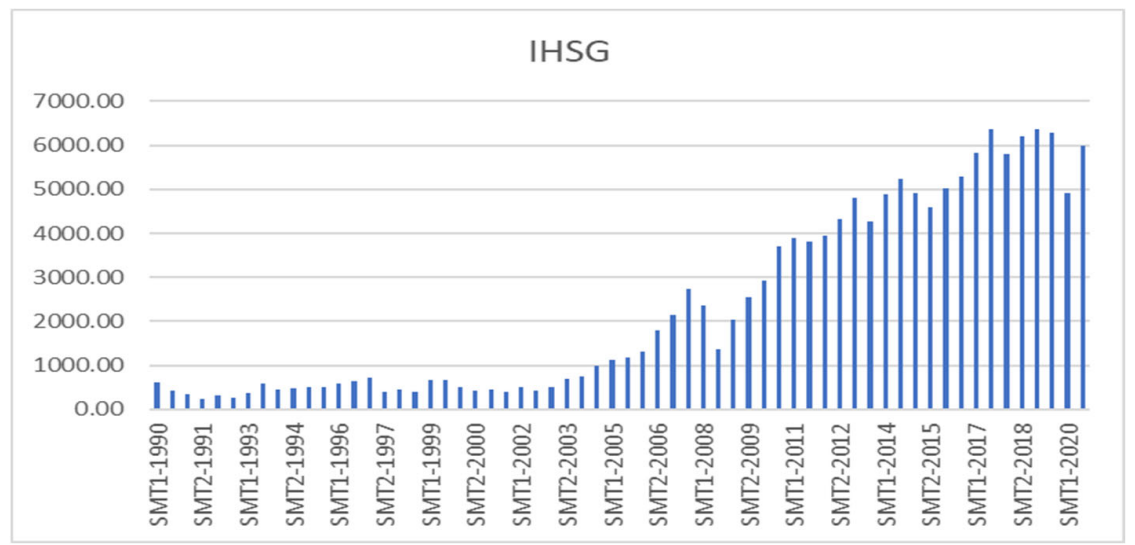

Fig. 3. Composite Stock Price Index 1990-2020

Source : Indonesia Stock Exchange, processed

Examination information on the Composite Stock Price Index during the years 1990-2020 has an ordinary worth of 2308.98. The most essential Composite Stock Price Index was recorded at 6358.63 in Semester I of 2019 and the most un-Composite Stock Price Index was recorded at 247.39 in Semester II of 1991.

In the graph above, it can be seen that the development of the Indonesian capital market through the Composite Stock Price Index (IHSG) during 1990 - 2007 continued to increase. In 2008 there was a decline due to the global economic crisis in 2008 where the JCI fell $60.73 \%$ from its highest level of $2,830.26$ to $1,111.39$, and was followed by a decline in market capitalization of $21.3 \%$. Furthermore, throughout 2009 to 2018 the JCI continued to increase, until it finally declined again in 2020 due to the impact of the Covid-19 pandemic. In light of information from the Central Statistics Agency, the pace of work during the 30 (thirty) research period 1990-2020 with semester information contained (62) research tests.

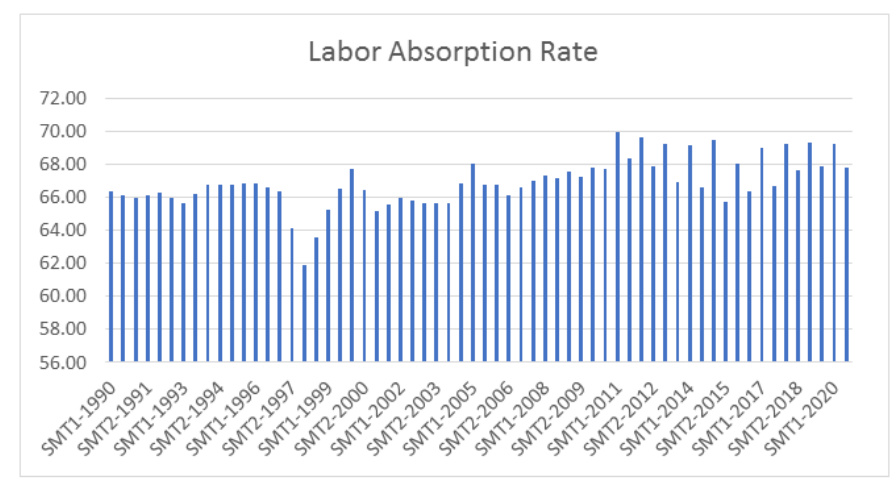

Fig. 4. Labor Absorption Rate 1990-2020

Source : Indonesia Stock Exchange, processed

Exploration information on the work assimilation rate during 1990-2020 has a normal worth of $66.90 \%$. The most noteworthy work retention rate was recorded at $69.96 \%$ in the 
principal semester of 2011 and the least work assimilation rate was recorded at $61.93 \%$ in Semester I of 1998. In the graph above, it can be seen that throughout 1990 to 1996 employment was in a stable condition, but in 1998 there was a significant decline, this was due to political and economic instability due to the monetary crisis which led to many layoffs (PHK). Then throughout 1999 it began to increase and was stable until 2019. In 2020 it began to experience a decline due to the Covid-19 pandemic which caused many layoffs (PHK). Based on data from the World Bank, Indonesia's per capita income during the 30 (thirty) research period 1990-2020 with semester information contained (62) research tests.

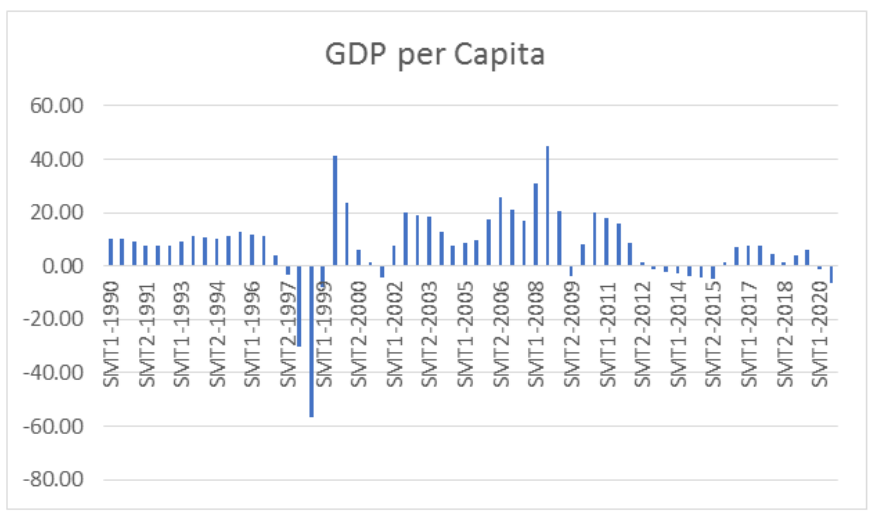

Fig. 5. Income per Capita 1990-2020

Source: World Bank, processed

Examination information on Income per Capita for 1990-2020 has a normal worth of $7.75 \%$. The most elevated per capita pay level was recorded at $44.85 \%$ in the primary semester of 2015 and the least for each capita pay level was recorded at $-56.86 \%$ in the second semester of 1998. In the graph above, it can be seen that Indonesia's income per capita throughout 1990 to 1997 experienced a stable condition. However, in 1998 there was immediately a significant decline to produce a minus value due to the monetary crisis at that time which caused Indonesia's GDP to become US $\$ 463.95$ per capita down by $50 \%$ compared to the previous year. Then it started to increase again in 2005 until 2008. In 2008 there was a significant increase in per capita income due to global economic developments and the improving capacity of Indonesia's domestic economy.

\subsubsection{Inferential Analysis}

The Influence of the Development, of the Indonesian Capital Market as proxied by the JCI on the Level of Labor Absorption in Indonesia. Through basic direct relapse showing the causal connection between the autonomous factors and the reliant variable are as per the following :

\section{a) Equation Model 1}

$\mathrm{LnZ}_{1}=\mathrm{b} 0+\mathrm{bLn} \_\hat{\mathrm{Y}}+€ \mathrm{t}$

$\mathrm{LnZ}_{1}=$ Indonesian Labor Absorption Rate 
b0 $=$ Constant Model 2

$\hat{\mathrm{Y}}=$ The Development of the Indonesian Capital Market (JCI)

$\mathrm{b}=$ Independent variable regression coefficient

$€ \mathrm{t}=$ Epsillon (Other factors outside of model 2)

Based on statistical calculations, the analysis of model 2 obtained the results as shown in the table below using the recursive method.

$\hat{\mathrm{Y}}=\mathrm{Y}+$ Residual Model I

Dependent Variable: LnZ1

Method: Least Squares

Date: 09/11/21 Time: 06:28

Sample: 162

Included observations: 62

Table 2. Multiple Linear Regression Model 1

\begin{tabular}{ccccc}
\hline Variable & Coefficient & Std. Error & t-Statistic & Prob. \\
\hline LnY & 0.016054 & 0.001522 & 10.54875 & 0.0000 \\
C & 1.774967 & 0.004830 & 367.4623 & 0.0000 \\
R-squared & 0.649689 & Mean dependent var & 1.825338 \\
Adjusted R-squared & 0.643850 & S.D. dependent var & 0.009616 \\
S.E. of regression & 0.005739 & Akaike info criterion & -7.451445 \\
Sum squared resid & 0.001976 & Schwarz criterion & -7.382828 \\
Log likelihood & 232.9948 & Hannan-Quinn criter. & -7.424505 \\
F-statistic & 111.2762 & Durbin-Watson stat & 0.731407 \\
Prob(F-statistic) & 0.000000 & & \\
\hline
\end{tabular}

Source: Data processed by EViews11

The results of the recursive calculations in Table 2 can be presented with the results of simple linear regression as follows: $\mathrm{LnZ}_{\mathbf{1}}=\mathbf{0 , 0 1 6 0 5 4}+\mathbf{1 , 7 7 4 9 6 7} \hat{\mathbf{Y}}$

The interpretation of the regression equation is as follows:

a. Constant value $=0.016054$ means that statistically if all ceteris paribus variables have a constant value, then the value of Indonesian Labor Absorption is 0.016054 .

b. The value of the regression coefficient $b=1.774967$ means that the elasticity value of the Indonesian Capital Market Development to the Absorption Rate of Indonesian Workers is $\mathrm{E}=1.774967$. The value of $\mathrm{E}>1$ indicates that the increase in the development of the Indonesian capital market is elastic to the level of absorption of Indonesian workers.

In light of the outcomes from table 2, it very well may be reasoned that the advancement of the Indonesian capital market on the pace of assimilation of Indonesian specialists dependent on the estimation results got by a basic straight relapse table, measurably shows huge outcomes on the likelihood worth of the improvement of the Indonesian capital market which is more modest than $(0.0000<0.05)$, it tends to be presumed that the Indonesian Capital Market Development variable has a huge and beneficial outcome on the Labor Absorption Rate. Understanding in the field of financial aspects implies huge implying that the theory of the improvement of the Indonesian Capital Market can be convincingly and definitively demonstrated to influence the degree of assimilation of Indonesian laborers. In the mean time, a positive arrangement implies that the expansion in the improvement of the Indonesian capital market is trailed by an increment in the pace of work retention in Indonesia. 
The greatness of the impact of the improvement of the Indonesian capital market on the pace of ingestion of Indonesian laborers is demonstrated by the worth of R-Squared = 0.649689, which implies that the enormous impact of the advancement of the Indonesian capital market on the pace of retention of Indonesian specialists is 64.96 percent, the excess 35.03 percent is affected by the accompanying variables: different elements outside the mode under study.

The Influence of the Development of the Indonesian Capital Market as proxied by the JCI on Income per Capita in Indonesia. Through basic direct relapse showing the causal connection between the autonomous factors and the reliant variable are as per the following:

\section{b) Equation Model 2}

$\mathrm{LnZ}_{2}=\mathrm{b} 0+\mathrm{bLn} \_\hat{\mathrm{Y}}+€ \mathrm{t}$

$\mathrm{LnZ}_{2}=$ Indonesia's Per Capita Income

b0 $=$ Constant Model 2

$\hat{Y}=$ The Development of the Indonesian Capital Market (JCI)

$\mathrm{b}=$ Independent variable regression coefficient

$€ \mathrm{t}=$ Epsillon (Other factors outside of model 2)

Based on statistical calculations, the analysis of model 2 obtained the results as shown in the table below using the recursive method.

$\hat{\mathrm{Y}}=\mathrm{Y}+$ Residual Model 1

Dependent Variable: LnZ2

Method: Least Squares

Date: 09/11/21 Time: 07:33

Sample: 162

Included observations: 62

Tabel 3. Multiple Linear Regression Model 2

\begin{tabular}{ccccc}
\hline Variable & Coefficient & Std. Error & t-Statistic & Prob. \\
\hline LnY & 23.04452 & 2.336988 & 9.860780 & 0.0000 \\
C & -64.34246 & 7.417357 & -8.674580 & 0.0000 \\
R-squared & 0.618406 & Mean dependent var & 7.961133 \\
Adjusted R-squared & 0.612046 & S.D. dependent var & 14.14797 \\
S.E. of regression & 8.812201 & Akaike info criterion & 7.221878 \\
Sum squared resid & 4659.294 & Schwarz criterion & 7.290495 \\
Log likelihood & -221.8782 & Hannan-Quinn criter. & 7.248819 \\
F-statistic & 97.23499 & Durbin-Watson stat & 1.599213 \\
Prob(F-statistic) & 0.000000 & & \\
\hline & Source: Data processed by EViews11
\end{tabular}

Source: Data processed by EViews11

The aftereffects of the recursive estimations in Table 3 can be given the consequences of straightforward direct relapse as follows: $\mathrm{LnZ}_{2}=-64.34246+23.04452 \hat{\mathrm{Y}}$

The interpretation of the regression equation is as follows:

a. Constant value $=-64,34246$ means that statistically if all ceteris paribus variables have a constant value, then the value of Indonesian Income per Capita is $-64,34246$

b. The value of the regression coefficient $b=23.04452$ means that the elasticity value of the Indonesian Capital Market Development to Indonesia's Income per Capita is E = 23.04452. 
The value of $E>1$ indicates that the increase in the development of the Indonesian capital market is elastic to Indonesia's per capita income.

In view of the outcomes from table 3, it tends to be reasoned that the Development of the Indonesian Capital Market on Indonesia's Income per Capita dependent on the computation results acquired by a straightforward direct relapse table, genuinely shows critical outcomes on the likelihood worth of the Indonesian Capital Market Development which is more modest than $(0,0000<0.05)$, it very well may be inferred that the Indonesian Capital Market Development variable has a huge and beneficial outcome on Income per Capita. Translation in the field of financial aspects implies critical implying that the speculation of the advancement of the Indonesian Capital Market can be convincingly and seriously demonstrated to influence Indonesia's Per Capita Income. In the interim, a positive arrangement implies that the increment in the advancement of the Indonesian capital market is trailed by an expansion in pay for every capita in Indonesia.

The extent of the impact of the advancement of the Indonesian capital market on the pay per capita of Indonesia is demonstrated by the worth of R-Squared $=0.6184$, implying that the impact of the improvement of the Indonesian capital market on the pay per capita of Indonesia is 61.84 percent, the leftover 38.16 percent is affected by different elements. others outside the mode under study.

\subsection{Discussion}

The Capital Market as an instrument can be used to increase the company's capital growth. This company's capital can later be used for capital expenditures, recruiting workers, mergers, acquisitions and research and development. The capital market is able to generate new jobs through small and medium enterprises, including entrepreneurship. According to the Venture Capital Association in the United States there is an additional $92 \%$ of jobs after the Initial Public Ofering (IPO).

In a market economy system, the capital market has two roles. First, in the primary market, a company conducting an IPO receives capital investment to expand its business, which often results in the creation of a significant number of jobs. In the secondary market, ongoing capital investment makes companies determine the rhythm of their business growth in an open stock exchange.

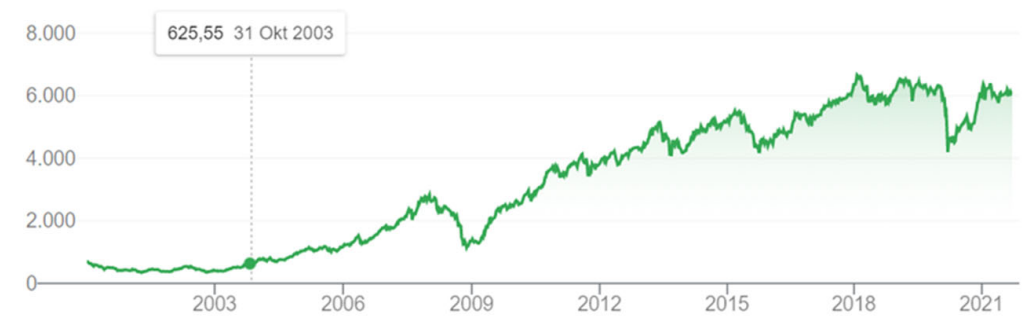

Fig. 6. Composite Stock Price Index 2003-2021 Source: Indonesia Stock Exchange

In Figure 6 above, you can see the movement of the Composite Stock Price Index from 2003 - 2021. The chart shows the Composite Stock Price Index (CSPI) experiencing an increasing trend from year to year, although there was a sharp decline in 2020 due to the 
Covid-19 pandemic. Labor absorption is the quantity of occupations that have been filled, which is reflected in the huge number of working individuals. The functioning populace is consumed and dispersed in different areas of the economy. The ingestion of the functioning populace is brought about by the interest for work.

Monetary development is typically trailed by a declining joblessness rate. The higher the pace of monetary development, the lower the joblessness rate and the higher the degree of work. As indicated by macroeconomic hypothesis, the elements that impact the assimilation of work are the degree of wages, the worth of creation and speculation. The capital market itself is one of the investment instruments for the community, the link between capital market development and employment is expected to increase investment both from within and outside the country, thus enabling companies to have fresh funds obtained during the IPO, these funds will be utilized to carry out business development, one of which involves the recruitment of workers.

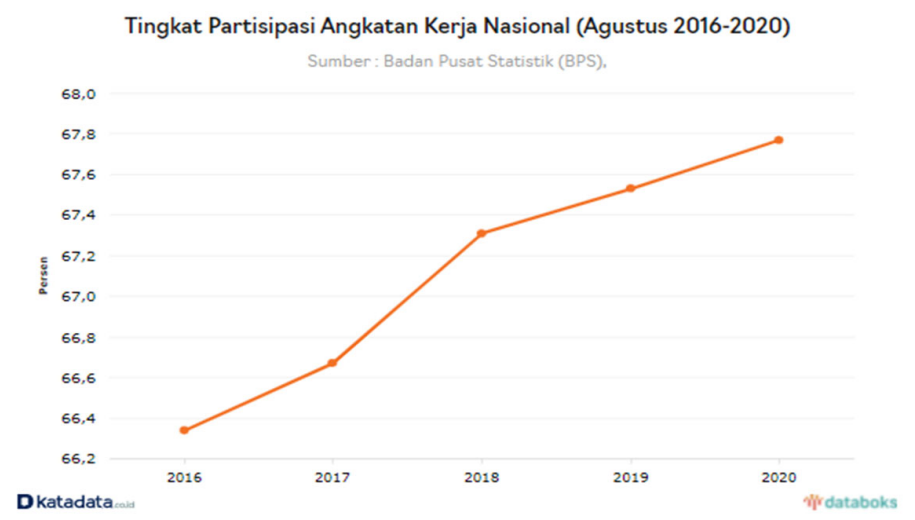

Fig. 7. National Labor Force Participation Rate Source : Databoks

In Figure 7 above, it can be seen the level of employment in the last 5 years 2016-2020. The graph shows that employment has experienced an increasing trend from time to time, presumably due to better economic stability.From the JCI chart and the labor absorption chart, it can be concluded that both data show an increasing trend, so it can be ascertained that one of the factors to increase employment is to build the improvement of the Capital Market in Indonesia.

Multiplier correlation between increase in investment and increase in national income. The multiplier correlation explains the correlation between investment and national income and consumption. If the investment increases, the national income and society will increase, as well as the level of consumption. The opinion of [17] states that the correlation between economic growth and investment is that an expansion in speculation will bring about an increment in public pay. This will build utilization which will ultimately prompt a further expansion in pay. This process tends to be cumulative in nature, the impact of which is an increase of course on investment which results in a soaring increase in income with a tendency to consume. So that investment is the most important factor in realizing the target of development and economic growth in a country. 
This is in line with the benefits of the Capital Market, because the capital market itself is a place to invest, both short-term and long-term investments. In addition, the Capital Market itself is a means of funding for companies or institutions that need funds to expand or develop their business. The relationship between the Capital Market and National Income is to increase the capital market from the perspective of investors, thus the level of production will also increase along with the increase in the market for goods and services. These two things are also closely related to the labor market mentioned earlier.

Contributions in the Capital Market will increase investment, further increasing investment will increase the country's economic development. From a macroeconomic perspective, investment has a positive relationship with national income. Especially in an effort to expand the use of labor which aims to increase income. The effect of the capital market on national income is formed from the multiplier effect caused by the formation of investment, so business people or people or the public authority contribute, then, at that point, there will be a sure measure of capital contributed, then, at that point, there are various acquisition of capital products that are not devoured, yet will be utilized. for creation. So the cycle can urge efficiency to create labor and products.

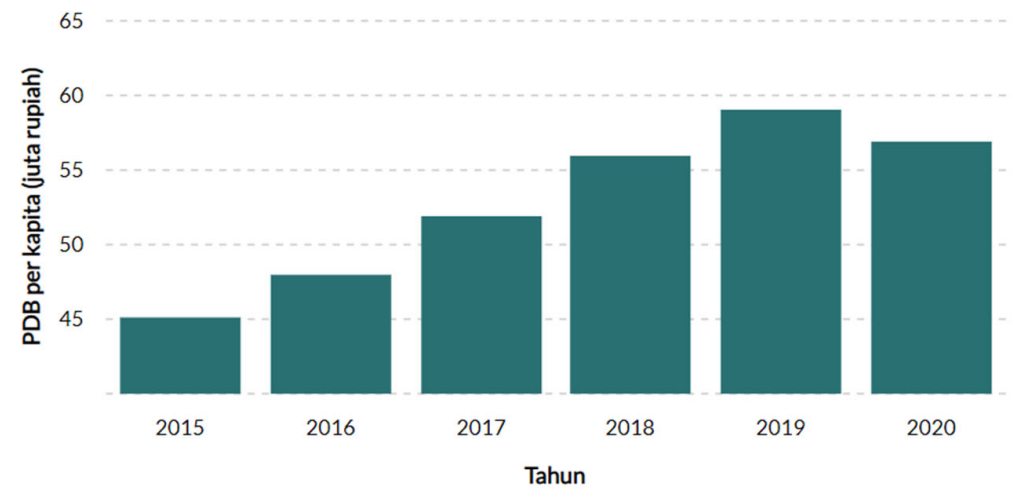

Fig. 8. Income per Capita Indonesia 2015-2020 Source : Databoks

In Figure 8 above, it can be seen that per capita income in the last 5 years 2015-2020. In the graph, it can be seen that per capita income has an increasing trend from time to time, it is suspected that economic stability is getting better, although it has decreased in 2020 due to the COVID-19 pandemic. The trend of the Income per Capita chart shows a similarity with the previous JCI chart. From the two graphs, it can be concluded that both data show an increasing trend and both decrease in 2020 due to the Covid-19 pandemic, so it can be assured that one of the factors in increasing Indonesia's per capita income is by increasing the development of the Capital Market in Indonesia.

National income and population are two things that influence the per capita income of a country. Per capita income is the average income of all residents in a country. The close relationship between the capital market as one of the main investment instruments in a country and national income will certainly have an impact on the per capita income of a country. 


\section{Conclusion and Suggestions}

\subsection{Conclusion}

The motivation behind this review was to decide the impact of the improvement of the Indonesian capital market on work assimilation and the expansion in per capita pay. Information were examined utilizing relapse with time series information in a semi-meter from 1990-2020. In view of the consequences of measurable tests acquired the accompanying outcomes:

1. Hypothesis 1: The development of the Indonesian capital market has a significant and positive impact on the labor absorption rate, "Supported".

2. Hypothesis 2: The development of the Indonesian Capital Market has a significant and positive impact on Per Capita Income, "Supported".

\subsection{Suggestions}

The suggestions that can be submitted are:

1. In association with the significance of the improvement of the Capital Market for monetary development as work and public per capita pay, it is suggested for the Indonesia Stock Exchange together with the Financial Services Authority and the Government to further promote and socialize capital market investment so that it can reach the realm of nonperforming only for large and urban companies but in the future, in order to be able to expand to the MSME level to be able to get funding through the capital market or participate in share ownership as an investment instrument, in the future it is also hoped that the inclusiveness of the capital market can penetrate to the countryside, with the target of BUMDes to can become a public company or conduct an Initial Public Offering (IPO), this will certainly increase funding for BUMDes so that they can expand or develop their business.

2. The inclusiveness of the Capital Market to the rural level (BUMDes) and Small Medium Enterprise Economic gives them the opportunity to become an even bigger business. With the increasing number of new companies growing, job creation will be wider in the future, with the number of workers absorbed, the aggregate production of goods or services will increase, so that it will have implications for increasing national income.

3. It is hoped that further researchers will carry out research using other variables that are not included in this study so that they can provide a clearer picture of Labor Absorption and increase in per capita income. And stakeholders are expected to be able to make strategies that can support national economic growth.

\section{References}

[1] S. Sukirno, Makroekonomi: Teori Pengantar. Jakarta: PT Raja Grafindo Pustaka, 2015.

[2] B. Kagi, "Labor force participation rate and economic growth: observations for Turkey," Univers. J. Manag. Soc. Sci., vol. 4, no. 4, pp. 46-54, 2014.

[3] Alfiat, "A Comprehensive Analysis of Poverty in India Asian," Dev. Rev., vol. 31, no. 1 , pp. 1-52, 2012.

[4] A. U. Haque, G. Kibria, M. I. Selim, and D. Y. Smrity, "Labor force participation rate and economic growth: Observations for Bangladesh," Int. J. Econ. Financ. Res., vol. 5, 
no. 9, pp. 209-213, 2019.

[5] A. Khaliq, D. Khan, S. Akbar, M. Hamayun, and B. Ullah, "Female Labor Market Participation and Economic Growth: The Case of Pakistan," J. Soc. Sci. Stud., vol. 4, no. 2, pp. 217-230, 2017.

[6] A. Sayed, C. Auret, and D. Page, "Do share prices lead economic activity in emerging markets? Evidence from South Africa using Granger-causality tests," Invest. Anal. J., vol. 46, no. 3, pp. 200-212, 2017.

[7] L. L. Albu, R. Lupu, and A. C. Calin, "A nonlinear model to estimate the long term correlation between market capitalization and GDP per capita in Eastern EU countries," J. Econ. Comput. Econ. Cybern. Stud. Res., vol. 3, pp. 5-22, 2014.

[8] J. M. Pastor, C. Peraita, L. Serrano, and Soler, "Lembaga pendidikan tinggi, pertumbuhan ekonomi dan PDB per kapita di negara-negara Uni Eropa," Stud. Perenc. Eropa, vol. 26, no. 8, pp. 1616-1637, 2018, doi: 10.1080/09654313.2018.148070.

[9] S. J. Claudia, "Interrelation Between Capital Market Index And Economic Growth: Comparison Among United-States, England And Japan, By Using Granger Causality Test." 2017.

[10] M. P. Todaro and S. C. Smith, "Economic Development (11th ed).New York:Pearson." 2012.

[11] Z. Emalia, "Analisis Konvergensi Produk Domestik Regional Bruto (Pdrb) Per Kapita Antarkabupaten/Kota di Propinsi Lampung. Tesis," Fak. Ekon. dan Bisnis UGM, Yogyakarta, 2011.

[12] M. P. D. Nazir, Metode Penelitian. Jakarta: Ghalia Indonesia, 2011.

[13] I. Putong, Economics Pengantar Mikro dan Makro. Jakarta: Mitra wacana Media, 2013.

[14] I. Fahmi, Analisis Kinerja Keuangan. Bandung: Alfabeta, 2012.

[15] Sunariyah, Pengantar Pengetahuan Pasar Modal (Edisi 6. Penerbit: UPP STIM YKPN, 2013.

[16] Soeroto, Strategi Pembangunan dan Perencanaan Tenaga Kerja. Jakarta: Gadjah Mada University Press, 2018.

[17] P. A. D. N. W. D. Samuelson, Ilmu Makro Ekonomi. Jakarta: PT Media Global Edukasi, 2014.

[18] Winardi, dalam Manajemen. Jakarta: PT. Rineka Cipta, 2016.

[19] W. Yuyun, "Kewirausahaan," in Buku Pegangan Jatinagor: UPTPenerbit IKOPIN, 2013.

[20] D. N. Gujarati, Dasar-dasar Ekonometrika, Edisi Kelima. Mangunsong, R.C. penerjemah. Jakarta: Salemba Empat, 2013. 